\section{Fertigation and Leaf Analysis Reduce Nitrogen Requirements of Pecans}

\author{
Ray E. Worley and \\ Benjamin G. M ullinix ${ }^{2}$
}

\begin{abstract}
Adpitional index words. Carya
\end{abstract} illinoeninsis fertilizer

\begin{abstract}
Summary. Yield and quality of pecan nuts were as high when $\mathbf{5 0}$ pounds $\mathrm{N} /$ acre was applied through a dripirrigation system as with 100 pounds/ acre (112 kg/ha-1) applied either all broadcast or half broadcasthalf fertigated. AlI N treatments kept leaf $\mathrm{N}$ well above the $2.50 \%$ (dry weight) lower threshold recommended for pecans. The $\mathbf{5 0}$ pounds $\mathrm{N} /$ acre-all-fertigated treatment resulted in less soil pH reduction and less loss of $\mathrm{K}, \mathrm{Ca}$, and $\mathrm{Mg}$ from soil in the nonwetted zone underneath the tree canopy than broadcast treatments. Soil pH , K, and Mg were slightly lowered in the 6- to 12-inch $(15$ to $30 \mathrm{~cm}$ ) soil layer when all of the $\mathrm{N}$ was fertigated. $\mathrm{H}$ igher leaf $\mathrm{Ca}$ and $\mathrm{Mg}$ from the low rate of $\mathrm{N}$ fertigated reflected the higher concentrations of these elements in the soil in the nonwetted zone rather than the lower concentrations in the wetted zone. There was no evidence of a detrimental effect on the tree from lowering the $\mathbf{N}$ application to only $\mathbf{5 0}$ pounds/ acre and applying it in four monthly applications through the drip irrigation system beginning $1 \mathrm{Apr}$.
\end{abstract}

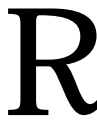
ecently, we reported the results of a study comparing broadcast vs. fertigation of $\mathrm{N}$ for pecan [Carya illinoeninsis(Wangenh) C. Koch] trees (Worley et al., 1995).

\footnotetext{
D epartment of $\mathrm{H}$ orticulture, C oastal Plain Experiment Station, Tifton GA 31794-0748.

${ }^{1}$ Professor

${ }^{2} \mathrm{~A}$ gricultural research statistician, Statistical and C omputer ServicesU nit.

The cost of publishing thispaper was defrayed in part by the payment of page charges. U nder postal regulations this paper ther fore must be hereby marked advertisement solely to indicate thisfact.
}

0 ver 10 years, there was no detrimental effect on yield or nut quality from reducing the $\mathrm{N}$ application from 200 to 100 pounds/ acre(224 to $\left.112 \mathrm{~kg} \cdot \mathrm{ha}^{-1}\right)$ and applying all of it through the dripirrigation system. $N$ itrogen rates were reduced the last 6 years by one-half in an effort to measure treatment differences. This report is of the last 6 years of the study. A similar $N$ fertigation study on peaches in Fort Valley, Ga. (Edwards et al., 1982), reported a substantial soil $\mathrm{pH}$ reduction in the wetted zone from fertigated N. L owering of the $\mathrm{pH}$ around emitters did not occur during the first 10 years, but calcium hydroxidehad been applied to neutralize the acid-forming effect of the $\mathrm{N}$. We wanted to verify that low $\mathrm{pH}$ would not be a problem over time with fertigation when no additional corrective measures were taken to prevent reduction of soil $\mathrm{pH}$ and to determine the long-term effects of fertigation on pecan tree yield, nut quality, and leaf analysis. G eorgiagrowersusually apply $>100$ pounds N / acre (112 kg $\cdot \mathrm{ha}^{-1}$ ) annually for pecans. If this could be halved, it would save more than $\$ 2$ million in a year in material costs in Georgia and reduce application costs, soil compaction, and pollution of surface and ground water.

\section{Materials and methods}

Thisstudy is acontinuation of the study reported previously (Worley et al., 1995) with the $N$ application rates halved from that of the first 10 years. Trees were 'Stuart' and 'Schley' estimated to be $>50$ years old growing on $\mathrm{R}$ ed Bay and G reenville soil. Thislocation is within the area and on soil types that produce about one-third of theworld'specans. Treesize, cultivars, and orchard history are typical of many older pecan orchards.

Treatments were 1) no irrigation, 100 pounds $\mathrm{N} /$ acre $\quad(112$ $\mathrm{kg} \cdot \mathrm{ha}^{-1}$ ) with all the $\mathrm{N}$ surfacebroadcast, half of the $\mathrm{N}$ was applied $\approx 1$ Apr. and theremainder $\approx 1$ June [broadcast not irrigated $(\mathrm{BNI})] ; 2$ ) applications. drip irrigation with 100 pounds N/ acre broadcast as for treatment 1 [broadcast irrigated (BI)]; 3) drip irrigation with 50 pounds $\mathrm{N} /$ acre (56 $\mathrm{kg} \cdot \mathrm{ha}^{-1}$ ) broadcast $1 \mathrm{Apr}$. as for treatment 1 plus 12.5 pounds N / acre (14 $\mathrm{kg} \cdot \mathrm{ha}^{-1}$ ) injected into the irrigation water (fertigated) $\approx 1$ A pr., 1 M ay, 1 June, and 1 July, for a total of 50 pounds N / acre fertigated [broadcastfertigated (BF)]; 4) no broadcast N with 50 pounds $\mathrm{N} /$ acre fertigated as for treatment 3 [half the rate of $\mathrm{N}$ all fertigated (1/ 2 F)]. Liquid U ran (16\% $\mathrm{N}$ from urea and $16 \% \mathrm{~N}$ from ammonium nitrate) was the $\mathrm{N}$ source for fertigation. The injection rate was 25 gallons/ $h\left(95 L \cdot h^{-1}\right)$ of the concentrated solution. Additional nutrients and lime were added uniformly to all trees each spring if leaf or soil analysis indicated need. These included 1 ton lime/ acre $\left(2240 \mathrm{~kg} \cdot \mathrm{ha}^{-1}\right)$ in 1991 and 70 poundsK/ acre $\left(78 \mathrm{~kg} \cdot \mathrm{ha}^{-1}\right)$ in 1993. All the broadcast $\mathrm{N}$ was from ammonium nitrate.

The statistical design was a split plot in a randomized complete block with three replications. $M$ ain plots consisted of eight insect control and cover crop treatments, and subplots consisted of the four irrigation-fertilizer treatments; therefore, each fertilizer-irrigation treatment wasreplicated 24 times. E ach irrigation-fertilizer subplot consisted of up to five trees and contained one or more 'Stuart' and 'Schley' trees each . A separate analysis was done for each cultivar for yield and nut quality data, but leaf and soil analyses were a composite from all trees within a plot. This paper concernsonly the results of the irrigation-fertilizer

Table 1. N umber of nuts to produce 1 pound $(0.454 \mathrm{~kg})$ of 'Stuart' and 'Schley' pecans from broadcast and fertigated N

\begin{tabular}{|c|c|c|c|}
\hline \multicolumn{4}{|c|}{ N application (pounds/ acre) } \\
\hline Broadcast & Fertigated & I rrigation & $\mathrm{N}$ uts/ pound ${ }^{2}$ \\
\hline \multicolumn{4}{|c|}{ Stuart } \\
\hline 100 & 0 & No & $76 \mathrm{~b}$ \\
\hline 100 & 0 & Yes & $66 a$ \\
\hline 50 & 50 & Yes & $67 a$ \\
\hline 0 & 50 & Yes & $66 a$ \\
\hline \multicolumn{4}{|c|}{ Schley } \\
\hline 100 & 0 & No & $103 \mathrm{c}$ \\
\hline 100 & 0 & Yes & $82 \mathrm{a}$ \\
\hline 50 & 50 & Yes & $85 \mathrm{~b}$ \\
\hline 0 & 50 & Yes & $82 \mathrm{a}$ \\
\hline
\end{tabular}

यM ean separation within each cultivar by general linear models with PDIFF option ( $t$ test) at $P=0.05$. 
subplot treatments. Statistical analysis was by general linear models analysis of variance with mean separation by the PDIFF option (t test) (SAS Institute, Cary, N.C.).

A line of emitterswasplaced within the herbicide strip on two sides of each tree and two 2-gallon/ $\mathrm{h}\left(7.6 \mathrm{~L} \cdot \mathrm{h}^{-1}\right)$ emitters were spaced $\approx 4$ feet $(1.2 \mathrm{~m})$ apart on each side of each tree on each line, for a total of eight emitters per tree. This recommended procedure places emitters on all sides of the tree with little overlap of the wetted zone
Fig. 1. Leaf $\mathbf{N}, \mathbf{C a}$, and $\mathrm{Mg}$ for pecan trees from broadcast (BC) and fertigated applications of $\mathbf{N}$. Mean separation by general linear models PDIFF option ( $t$ test) at $P=0.05$. The horizontal line is the lower threshold of the normal range for each nutrient.
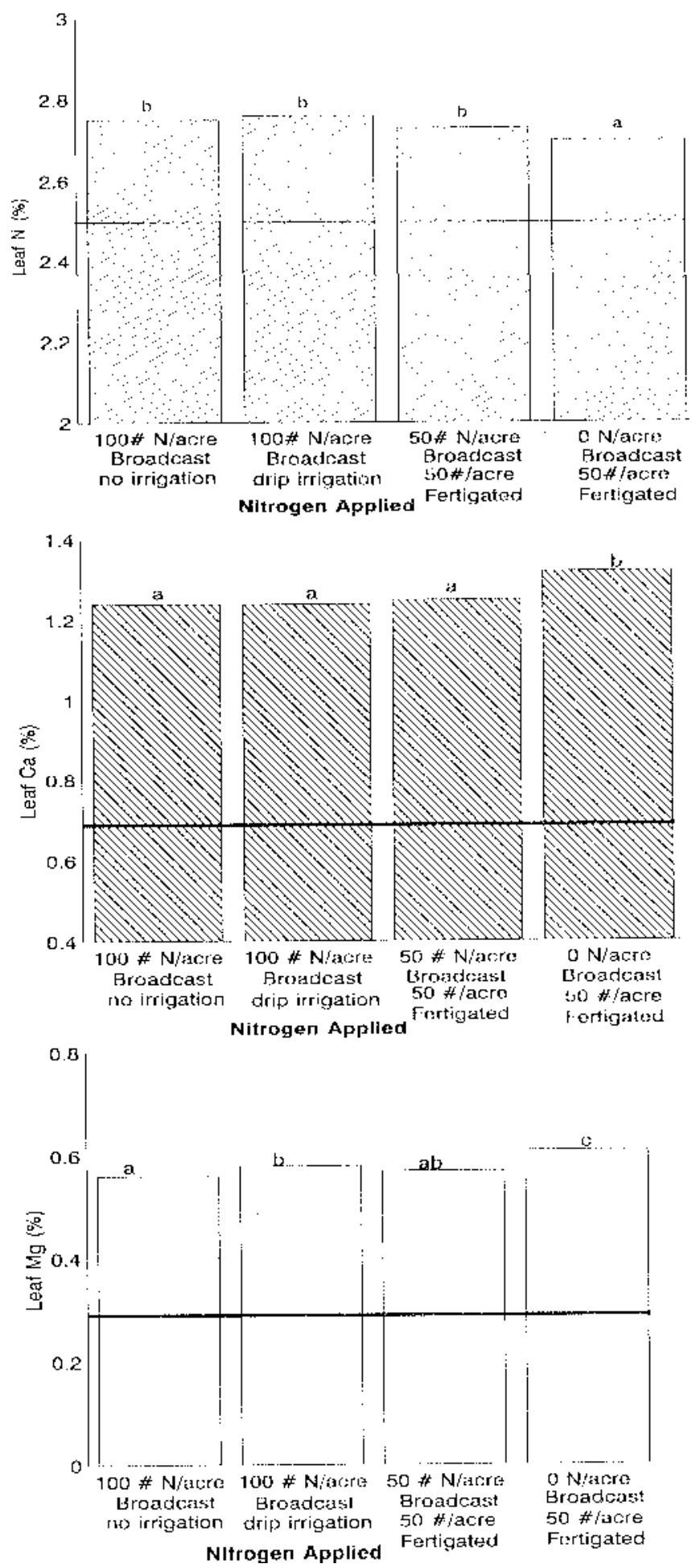

and within the weed-free herbicide strip where they can be seen and serviced easily. When fertigating, the valves for the irrigation lines for $\mathrm{BI}$ were turned off and the specified volume of $U$ ran was pumped through the system onto the $B F$ and $1 / 2 F$ treatment trees. All irrigated trees received the same amount of irrigation water except for the four times each year when fertigation occurred. The irrigation system was o perated $\geq 1 \mathrm{~h}$ (usually overnight) after each fertigation to flush the system and distribute the $\mathrm{N}$ through the wetted zone. Additional irrigation was applied $12 \mathrm{~h} \cdot \mathrm{d}^{-1}$ beginning $\approx 3 \mathrm{~d}$ after each 1 -inch $(2.5 \mathrm{~cm})$ rain during the growing season or if there was visual indication of need. This method approximates recommended irrigation practices for growers in the area.

Yield and quality data were taken for each tree annually. A 50-nut sample was taken from each tree at harvest, sized by categories separated by $1 / 16$ inch $(0.16 \mathrm{~cm})$ of diameter, and then cracked. Kernels were graded into fancy, standard, and amber grades, and percentage of each size, kernel grade, and total percentage ediblekernel was calculated. Fancy kernels were plump, well-filled kernels of the brightest color. Standard kernels were similar but darker. Amber kernels were darker than standard kernels or had edible kernels with defects.

L eaf sampleswere taken from each plot between the second week in July and the first week of August (Plank, 1989), and soil samples were taken in winter each year. The samples were analyzed using an atomic absorption spectrophotometer for cations, colorometric proceduresfor $\mathrm{P}$ ( $\mathrm{G}$ aines and $M$ itchell, 1979) and Kjeldahl (H elrich, 1990) for $N$. Additional soil samples were taken within 1 to 2 feet (30 to $60 \mathrm{~cm}$ ) of each emitter to determine the effect of fertigation on soil in the wetted zone.

\section{Results and discussion}

Irregular bearing, common to pecan trees, was well in evidence over the 6 years. Yield of 'Schley' was very low $[<10$ pounds per tree $(4.5 \mathrm{~kg} /$ tree) ] in 1990 and 1991 and was essentially zero in 1995 . Yield was fair [ $>65$ pounds per tree $(30 \mathrm{~kg} /$ tree $)$ in 1994. 'Stuart' yield was good [ $>80$ pounds per tree (36 kg/ tree)] in 1991, 1993, and 1994 and <30 pounds per 
tree (14 kg/ tree) in other years. The response from irrigation was not significant. Theyear 1994 was the year of the great flood in that county when $>21$ inches $(53 \mathrm{~cm})$ of rain fell within $24 \mathrm{~h}$; however, the orchard was not flooded. Yield was as high for $1 / 2 \mathrm{~F}$ as for any of the other treatments (data not shown). Kernel quality grades and total percent kernel were similar for all treatments (data not shown). Larger nuts were produced by both cultivars when irrigation was provided than when not irrigated. With irrigation, nuts were as large or larger for $1 / 2 \mathrm{~F}$ as for any of theo ther treatments(Table1).

0 ther experimentshaveindicated that a leaf $\mathrm{N}$ concentration of $2.75 \%$ is sufficient for optimum tree growth, nut yield, and nut quality (O 'Barr, 1985; Worley, 1985, 1990). Thelower threshold used by the pecan leaf analysis program is $2.50 \%$ (Plank, 1989). The mean leaf $\mathrm{N}$ concentration for
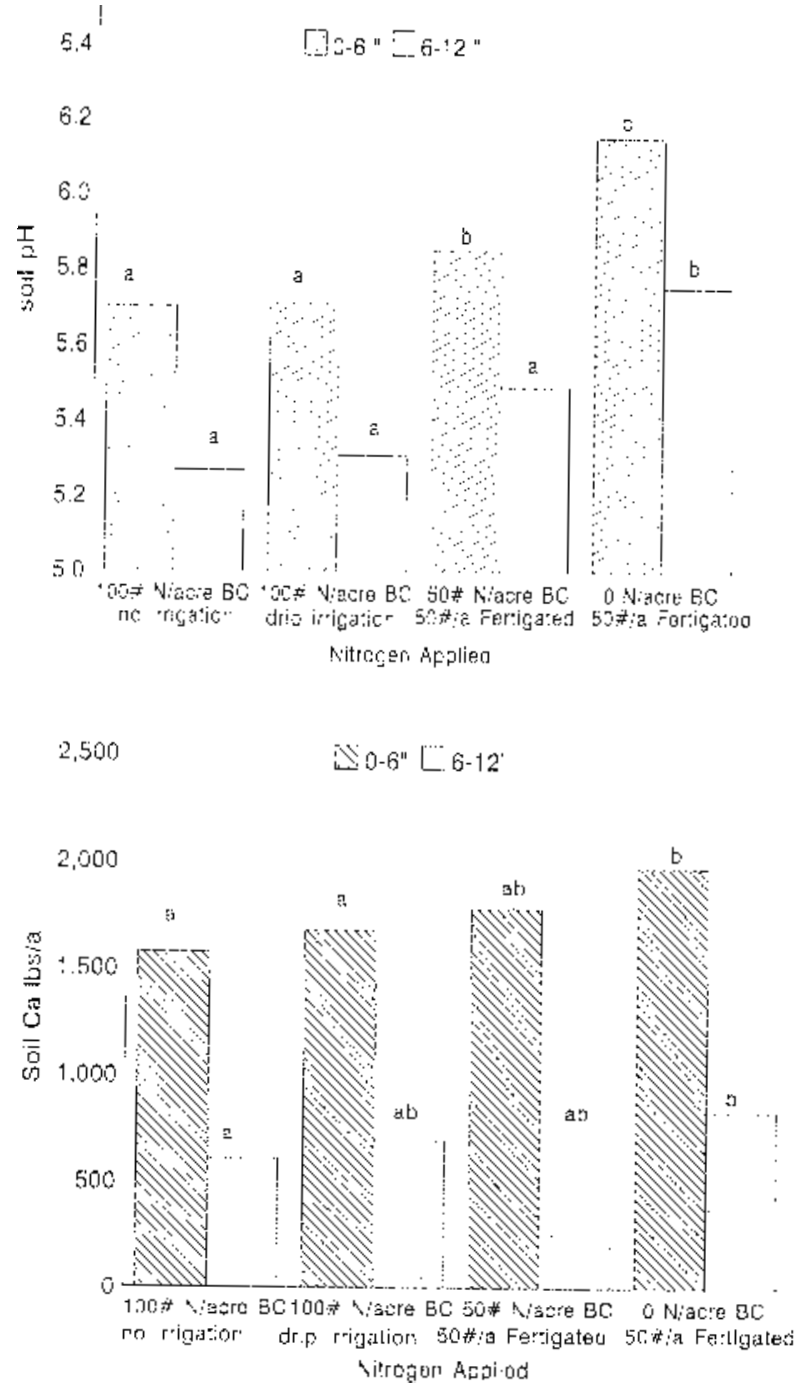

1/ $2 \mathrm{~F}$ was $2.70 \%$, well abovethethreshold for the normal range (Fig. 1). Although this value was statistically less than that for the other treatments, the difference was 0.06 percentage points or less and suggests greater efficiency for fertigation; however, the test does not confirm this because there were no broadcast treatments at the low rate. Percentage of leaf dry matter was not measured. All treatments supplied abundant N (Fig. 1). $D$ ifferences in leaf mineral concentration between treatments, although sometimesstatistically significant, were small. L eaf $\mathrm{C}$ a and $\mathrm{M} g$ were higher for $1 / 2 \mathrm{~F}$ than for other treatments (Fig. 1 ), but again, leaf $\mathrm{Ca}$ and $\mathrm{Mg}$ were abundant for all treatments. $\mathrm{H}$ igh leaf $\mathrm{Ca}$ and $\mathrm{Mg}$ concentrations for the $1 / 2 \mathrm{~F}$ treatment reflect higher concentrations of these elements in the nonwetted soil away from the emitter rather than the lower concentrations of these elements in the wetted zone around the emitter, and suggests that the soils of the nonwetted zone are relatively important in leaf nutrition.

The acid-forming effect of $\mathrm{N}$ on soil was in effect, although of low magnitude. $\mathrm{N}$ itrogen applicationsusually lower $\mathrm{pH}$ and soil cations $\mathrm{K}, \mathrm{Ca}$, and $\mathrm{M} g$ in the locationsapplied. When all $\mathrm{N}$ was fertigated, the nonwetted soil in the area away from the emitters received no $\mathrm{N}$, resulting in soil $\mathrm{pH}, \mathrm{K}$, $\mathrm{Ca}$, and $\mathrm{Mg}$ being highest for $1 / 2 \mathrm{~F}$ and lowest for the all-broadcast plots (Fig. 2). Conversely, when all the $\mathrm{N}$ wasfertigated, the $\mathrm{N}$ wasconcentrated in the wetted zone, resulting in a lowering of $\mathrm{pH}$ and soil $\mathrm{K}$ and $\mathrm{Mg}$ in the 6 - to 12 -inch ( 15 to $30 \mathrm{~cm}$ ) layer. The differences were not as apparent in the 0 - to 6-inch layer (Fig. 3) and werenot significant for $\mathrm{Ca}$ in either layer. Soil characteristics all were lower in the wetted zone than in the nonwetted
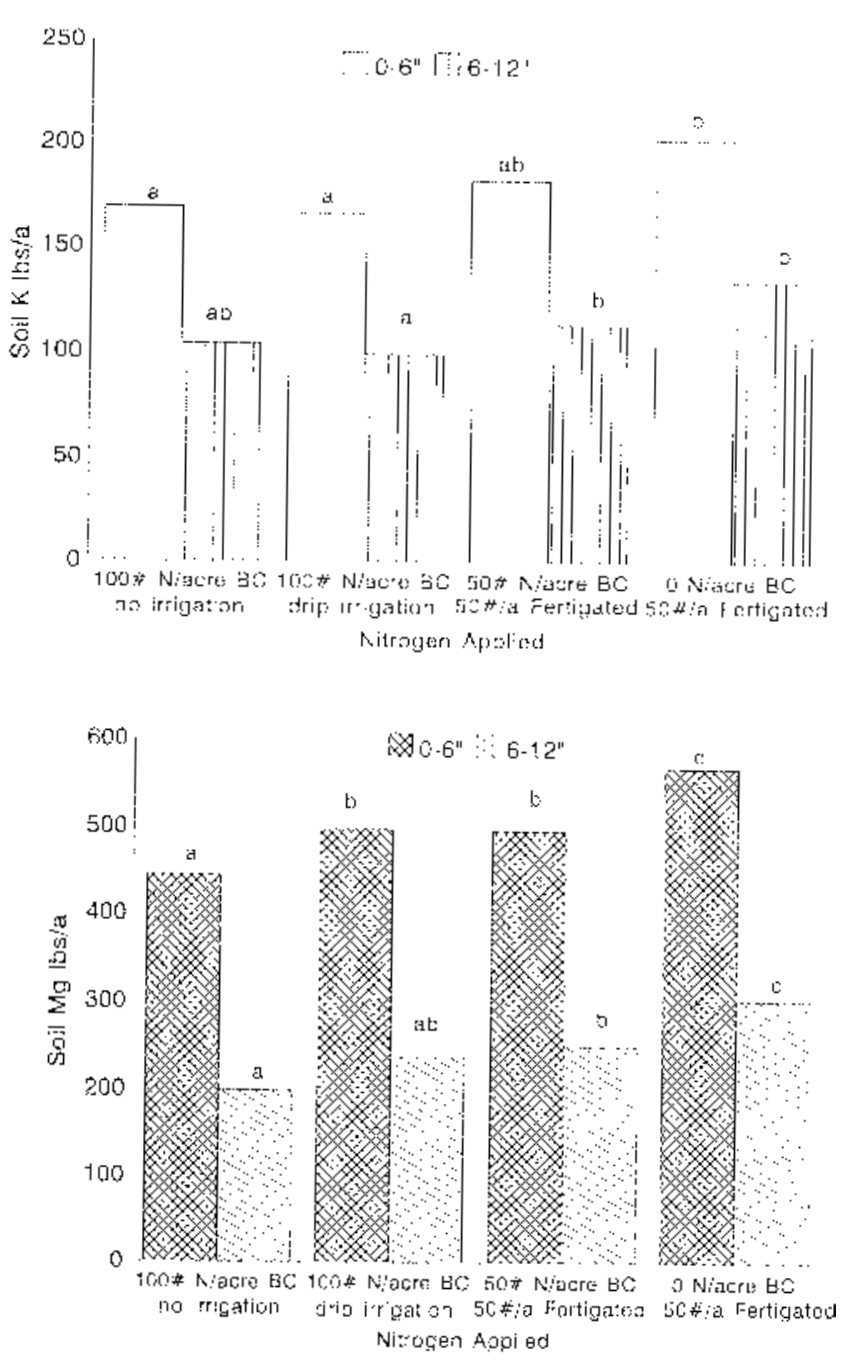

Fig. 2. Soil $\mathrm{pH}, \mathrm{K}, \mathrm{Ca}$, and $\mathrm{Mg}$ in the nonwetted area outside the wetted zone of the drip-irrigation emitter when $\mathrm{N}$ was broadcast (BC) and fertigated. Mean separation within each depth by general linear models PDIFF option (t 
zone (Table 2), which is opposite to that revealed in the first 10 years. The reason could be due to cultivation of the nonwetted area between trees during the last 6 years. The cultivation may have mixed surface-applied lime and fertilizers to make them more detectable by soil sampling. The wetted area could not be cultivated because of the drip-irrigation lines. No cultivation was done the first 10 years.
There was no evidence of a progressive lowering of the soil $\mathrm{pH}$ in the wetted zone over time; in fact, the opposite trend was occurring (Fig. 4). The significant year $\times$ treatment interaction was caused by the relative increasesin $\mathrm{pH}$ of $\mathrm{BI}$ over yearscompared with $\mathrm{BF}$ and $1 / 2 \mathrm{~F}$. All treatments increased with time, but $\mathrm{BI}$ started with a lower $\mathrm{pH}$ than $1 / 2 \mathrm{~F}$ in 1990 and increased at a faster rate than the other
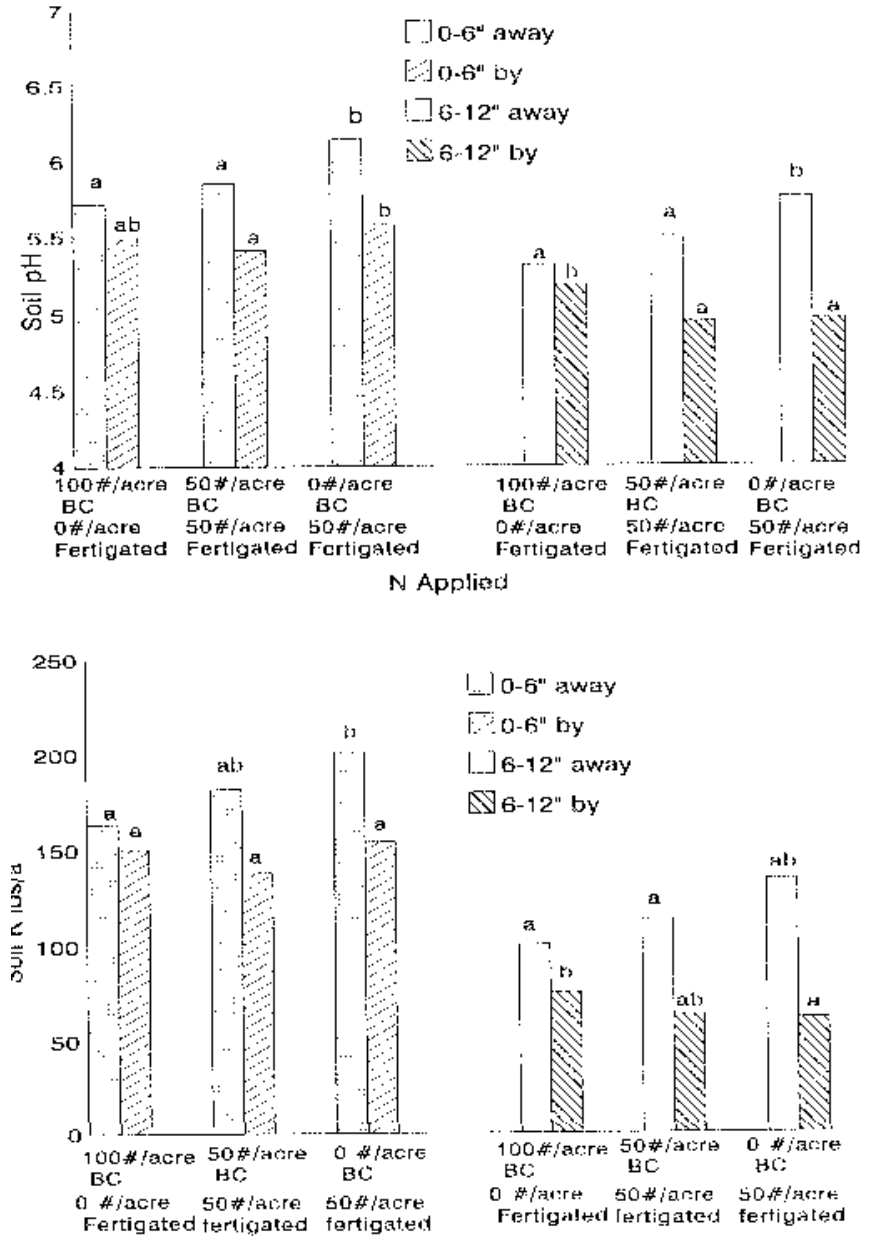

$$
\begin{aligned}
& \text { J 0-6" awity }
\end{aligned}
$$

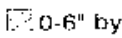

$$
\begin{aligned}
& \text { L_]6-12" away } \\
& \text { ब6-12" by }
\end{aligned}
$$

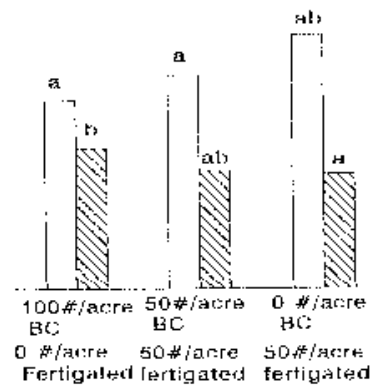

N Applied

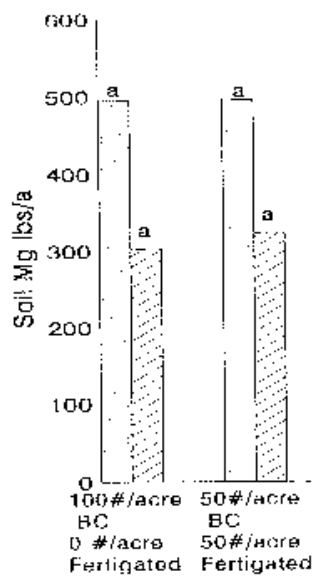

L_ J-6" away

1 $10-6^{\prime \prime}$ by

- 612 away

N6.12" by

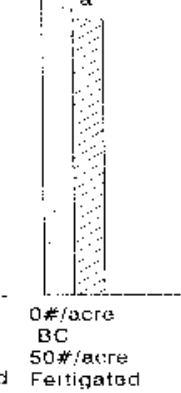

$N$ adolien

treatmentscausing a crosso ver interaction. The high concentration of basic cations in the irrigation water probably neutralized much of the acid formed by the $\mathrm{N}$. An analysis of the irrigation water revealed $\mathrm{Ca}, \mathrm{Mg}$, and $\mathrm{N}$ a at $0.95,1.81,4.11 \mu \mathrm{g} \cdot \mathrm{g}^{-1}$, respectively.

The data from this study indicate that aN application of only 50 pounds/ acre $\left(56 \mathrm{~kg} \cdot \mathrm{ha}^{-1}\right)$, if fertigated in four monthly applications, can supply pecan trees with an adequate supply of $\mathrm{N}$ without causing a serious reduction of $\mathrm{pH}$ or loss of other nutrients in the wetted zone of the drip emitter. The reduction in $\mathrm{pH}$ and lowering of soil $\mathrm{K}$ and $\mathrm{Mg}$ in the 6 - to 12 -inch layer of the wetted zone was not reflected in pecan leaves. The leaf analyses do not indicateany nutritional problemsfrom supplying all of the $\mathrm{N}$ by drip irrigation. The lowering of $\mathrm{pH}$ and loss of $\mathrm{K}$ and $\mathrm{Mg}$ in the 6 - to 12 -inch soil layer does indicate that a correction might be needed if irrigation water does not contain sufficient basic cations to neutralize the acidity produced by the $\mathrm{N}$. Thiscorrection could beaccomplished with calcium nitrate or other soluble sources of basic cations. Early results from studies at another location indicate that using calcium nitrate as a $\mathrm{N}$ source is effective in maintaining $\mathrm{pH}$ and soil nutrients.

\section{Literature Cited}

Edwards, J.H., R .R. Bruce, B.D. H orton, J.L.Chesness, and E.J. We hunt. 1982. Soil cation and water distribution as affected by $\mathrm{N} \mathrm{H}_{4} \mathrm{NO}_{3}$

T able 2. A comparison of soil characteristics inside and outside the wetted zone of the drip-irrigation emitter.

\begin{tabular}{lcc}
\hline Variable & $\begin{array}{c}\text { Nonwetted } \\
\text { zone }\end{array}$ & $\begin{array}{c}\text { Wetted } \\
\text { zone }^{z}\end{array}$ \\
\hline 0 to 6 inches & & \\
pH & 5.90 & 5.49 \\
$\mathrm{P}$ (pound/ acre) & 96 & 59 \\
$\mathrm{~K}$ (pound/ acre) & 182 & 147 \\
$\mathrm{Ca}$ (pound/ acre) & 1793 & 1084 \\
$\mathrm{Mg}$ (pound/ acre) & 518 & 328 \\
6 to 12 inches & & \\
$\mathrm{pH}$ & 5.51 & 5.03 \\
$\mathrm{P}$ (pound/ acre) & 41 & 26 \\
$\mathrm{~K}$ (pound/ acre) & 116 & 67 \\
$\mathrm{Ca}$ (pound/ acre) & 739 & 524 \\
$\mathrm{Mg}$ (pound/ acre) & 262 & 141
\end{tabular}

${ }^{\mathrm{z} A l l}$ variables were significantly lower in the wetted zone than the nonwetted zone. 

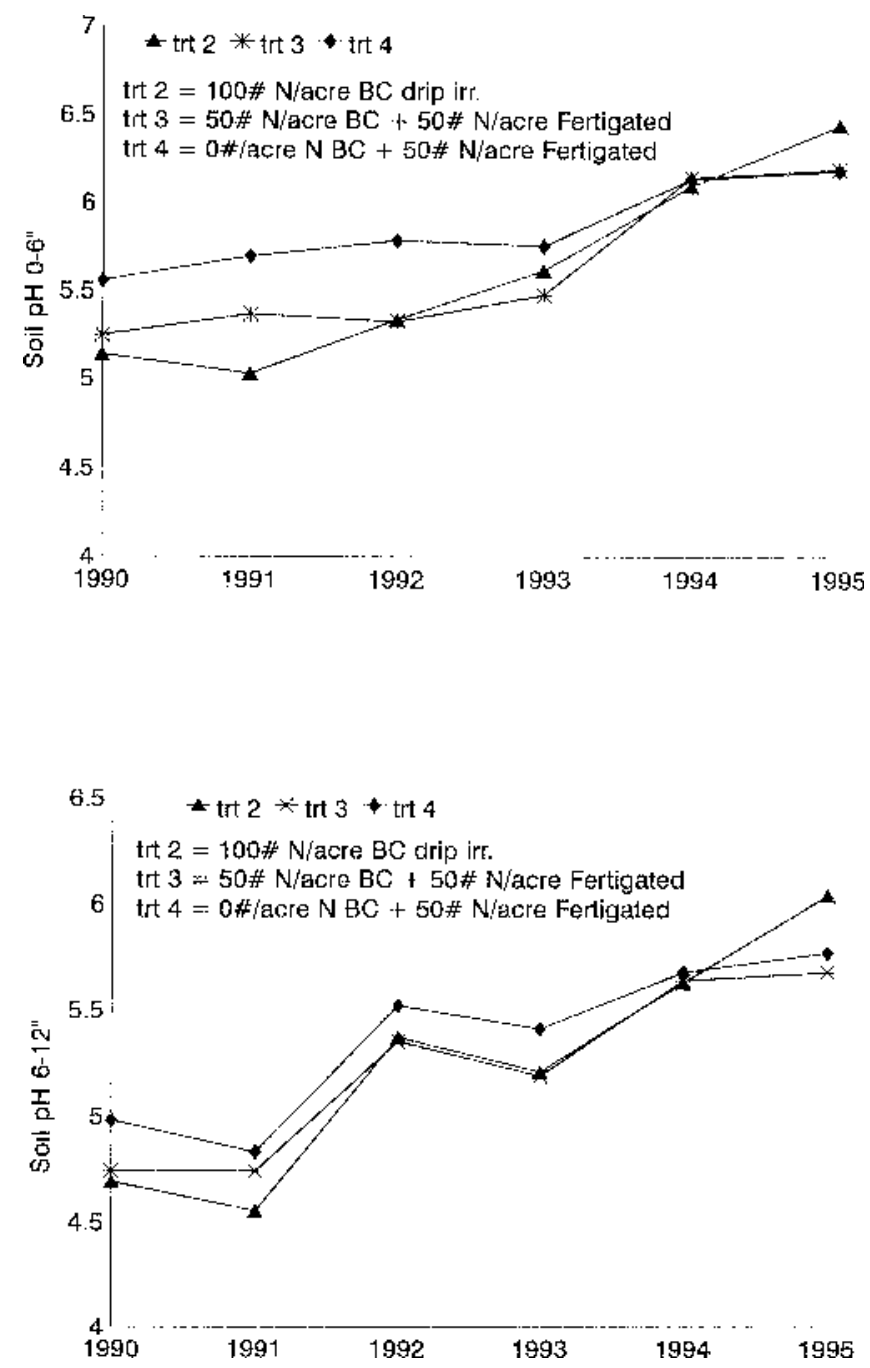

Fig. 4. Soil pH in the wetted zone of the emitters in the 0- to 6 and 6- to 12inch layer over years and method and rate of $N$ application. The year $¥$ fertilization interaction was significant. $B C=$ broadcast, Fert. $=$ fertigated.

applied through a drip irrigation system. J. Amer. Soc. H ort. Sci. 107:1142-1148.

Gaines, T.P. and G.A. Mitchell. 1979. Chemical methods for soil and plant analysis. U GA CPES Agron. H dbk. no. 1.

Helrich, K. (ed.). 1990. Official methods of analysis of the Association of Agricultural C hemists. 15th ed. vol. 1, p. 74, Section 984.13. Assn. of $\mathrm{O}$ fficial A gricultural Chemists, Washington, D.C.

O'Barr, R.D. 1985. LSU pecan nutritional research. Proc. Southeastern Pecan G rowers Assn. 78:93-100.

Plank, C.O. 1989. Plant analysis handbookforGeorgia(unnumbered special publication).
W orley, R.E. 1985. U se of leaf analysis for basing $\mathrm{N}$ applications for Stuart pecans. Proc. Southeastern Pecan Growers Assn. 78:79-83.

W orley, R .E. 1990. Long-term performance of pecan trees when nitrogen application is based on prescribed threshold concentrationsin leaf tissue. J. Amer. Soc. H ort. Sci. 115:745-749.

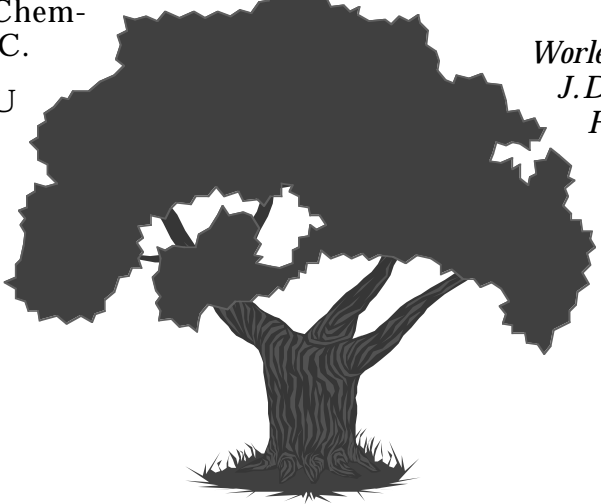

Assessing

Vascularization Response of Three Tomato (Lycopersicon esculentum Mill.) Cultivars to Soil Type, Nutrient Stress, and Water Stress

\author{
D ouglas C. Sanders ${ }^{1}$, \\ J ennifer D. Cure², \\ Pamela M . D eyton ${ }^{3}$, and \\ Randolph G. Gardner ${ }^{4}$
}

Additional indeX words. fruit quality

Summary. Amount of vascular development (veininess) is an important quality factor for processing wholepack tomatoes. The influences of nutrient and soil moisture stress on the amount of vascular development in 'C hico III', 'D orchester', and 'R oma' tomato fruit were studied. Fruit subjected to nutrient stress showed the highest amount of veininess. Fruit exposed to moisture stress after initial fruit set did not differ from controls in amount of veininess. Amount of vascularization did not differ among cultivars. A method for quantifying veininess was developed and compared with a traditional subjective rating scale. There was a high correlation $\left(r^{2}=\right.$ 0.77 ) between the subjective rating and quantitative measurement of veininess.

1Professor, D epartment of $\mathrm{H}$ orticultural Science $\mathrm{N}$ orth Carolina StateU niversity, R aleigh, N C 27695-7609.

${ }^{2} \mathrm{R}$ esearch associate, $\mathrm{D}$ epartment of $\mathrm{H}$ orticultural Science, N orth Carolina State U niversity, R aleigh, N C 27695-7609.

${ }^{3}$ Former graduate student, Department of $\mathrm{H}$ orticultural Science, N orth Carolina State U niversity, Raleigh, N C 27695-7609.

${ }^{4}$ Professor, D epartment of $\mathrm{H}$ orticultural Science, M ountain $\mathrm{H}$ orticultural $\mathrm{C}$ rops $\mathrm{R}$ esearch and Extension Station, 2016 Fanning Bridge R oad, Fletcher, N C 28732.

The cost of publishing thispaper wasdefrayed in part by the payment of page charges $U$ nder postal regulations, this paper therefore must be her eby marked advertisement solely to indicate thisfact. 